\title{
Peripheral blood eosinophil counts and bronchial responsiveness
}

\author{
K J TAYLOR, A R LUKSZA \\ From the Department of Thoracic Medicine, Fazakerley Hospital, Liverpool
}

ABSTRACT Bronchial responsiveness (histamine $\mathrm{PC}_{20}$ ) and peripheral blood eosinophil counts weref measured in 23 asthmatic subjects, of whom 14 were atopic and nine non-atopic. In the group as a.o whole there was an inverse correlation between baseline eosinophil count and histamine $\mathrm{PC}_{20}$ $(r=-0.71 ; p<0.001)$. For atopic subjects a relationship between eosinophil count and histamine $\mathrm{PC}_{20}$ was observed $(\mathrm{r}=-0.74 ; \mathrm{p}<0.01)$, but there was no correlation between eosinophil count $\mathrm{f}_{-}$ and baseline $\mathrm{FEV}_{1}$ or baseline $\mathrm{FEV}_{1}$ and histamine $\mathrm{PC}_{20}$. For the non-atopic subjects a similar relationship between eosinophil count and histamine $\mathrm{PC}_{20}$ was seen $(\mathrm{r}=-0.68 ; \mathrm{p}<0.05)$ and $\mathrm{a}=$ less significant inverse correlation between baseline eosinophil count and baseline $F_{E V} \overrightarrow{0}_{\overrightarrow{0}}$ $(r=-0.65 ; p<0.05)$. These results show a relationship between eosinophil count and non-specific bronchial responsiveness in both atopic and non-atopic asthma.

Eosinophilia in association with reversible airways obstruction has been recognised since the early $1900 \mathrm{~s}$ but the precise role of the eosinophil has not been fully established. It appears to have the potential for a dual role, on the one hand releasing enzymes capable of degrading mast cell mediators and modulating their effects ${ }^{1}$ but on the other contributing to tissue damage by deposition of major basic protein in the bronchi. ${ }^{2}$ In patients with stable asthma the peripheral blood eosinophil count shows wide variation ${ }^{3}$ and eosinophilia does not differentiate atopic from non-atopic asthma. In non-atopic asthma a relationship between the peripheral blood eosinophil count and the $\mathrm{FEV}_{1}$ has been observed and the eosinophil count shown to be useful in monitoring disease activity. ${ }^{4}$ In addition, a relationship between eosinophil count and methacholine $\mathbf{P C}_{20}$ has been observed in subjects with allergen induced late phase asthmatic reactions. ${ }^{5}$

We have investigated the relationship between the peripheral blood eosinophil count and bronchial responsiveness determined by histamine challenge in subjects with atopic and non-atopic asthma.

Address for reprint requests: Dr K J Taylor, Department of Geriatric Medicine, St Thomas's Hospital, Stockport SK3 8BL.

Accepted 15 December 1986

\section{Methods}

PATIENTS

Twenty three asthmatic patients who were not takingo systemic steroids were studied. The 14 atopic patients (six male, eight female) had a mean age of 33 (range 16-74) years. The nine non-atopic patients (threemale, six female) had a mean age of 44 (range 35-58) years. All patients gave their informed consent before the study, which was approved by the local ethical committee. The diagnosis of asthma was based on a 3 history of episodic dyspnoea and recorded variabilityo in $\mathrm{FEV}_{1}$ of more than $20 \%$. The atopic subjects were defined as having positive skinprick test responses to at least one common allergen and a history of asthma or hay fever in first degree relatives. The non-atopico group had negative skin test responses and no such family history. Inclusion in the study required that they were relatively symptom free but having treat 0 ment and had not experienced intercurrent respiratory tract infection during the preceding month.

The group contained three current smokers and one ex-smoker; the rest were lifelong non-smokers? (table). Altogether five subjects were inhaling sodiums cromoglycate, eight corticosteroid, and one both drugs (table). All subjects inhaled $\beta$ agonists when they had symptoms and one subject was taking ora theophylline.

HISTAMINE CHALLENGE TEST

Patients continued their usual medication but with- 
Data on the subjects

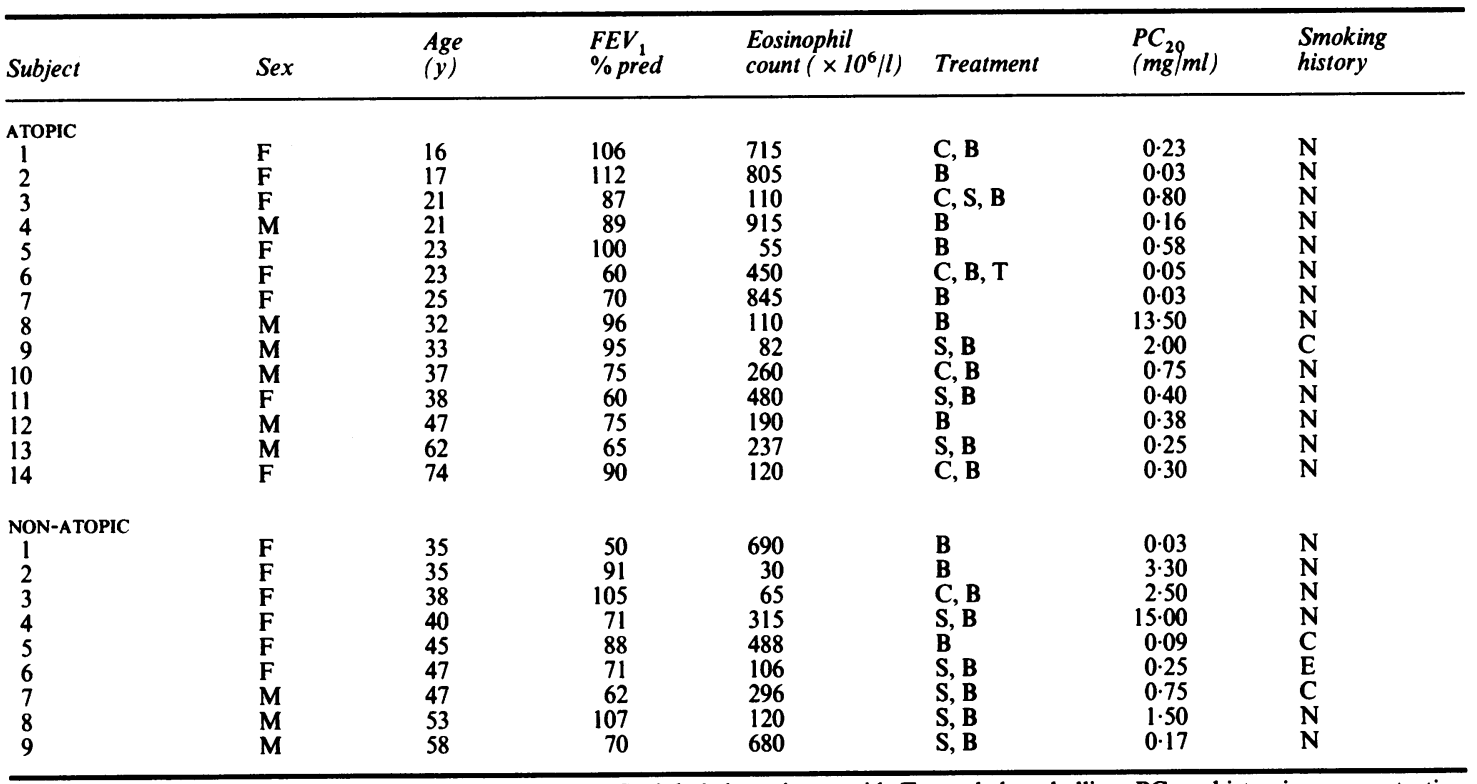

B-inhaled $\beta$ agonist; $\mathrm{C}$-inhaled sodium cromoglycate; $\mathrm{S}$-inhaled corticosteroid; $\mathrm{T}$-oral theophylline; $\mathrm{PC}_{20}$ - histamine concentration causing $20 \%$ fall in $\mathrm{FEV}_{1} ; \mathrm{C}$-current smoker; $\mathrm{E}$-ex-smoker; $\mathrm{N}$-lifelong non-smoker.

held inhaled $\beta$ agonists for 12 hours and oral theophylline for 48 hours before testing. The method of Cockcroft et $a l^{6}$ was employed except that Acorn nebulisers were used. After baseline spirometry, aerosols of test solutions were generated by passing oxygen through the nebulisers at a flow rate of $61 \mathrm{~min}^{-1}$. The same nebulisers were used for given concentrations of histamine throughout, their outputs having previously been calibrated. Aerosols were inhaled by tidal breathing for two minutes. First phosphate buffered saline was inhaled, followed at five minute intervals by doubling concentrations of histamine acid phosphate, starting at $0.03 \mathrm{mg} / \mathrm{ml}$. The Vitalograph dry bellows spirometer was used for measurements of $\mathrm{FEV}_{1}$ and predicted values were obtained. ${ }^{7}$ The FEV 1 was measured at 30 and 90 seconds after each inhalation; the lower of the two values was used and the test was discontinued when the $\mathrm{FEV}_{1}$ had fallen by more than $20 \%$ of the value obtained after inhalation of phosphate buffered saline. The concentration of histamine required to cause a $20 \%$ fall in the $\mathrm{FEV}_{1}\left(\mathrm{PC}_{20}\right)$ was obtained from the log doseresponse curve. All tests were performed between 10.00 and 12.00 hours.

\section{EOSINOPHIL COUNTS}

Venous blood was taken just before histamine challenge testing and put into a tube containing EDTA. Eosinophil counts were performed with a FuchsRosenthal counting chamber. ${ }^{8}$ The EDTA blood was added to diluting fluid containing $10 \mathrm{ml}$ aqueous eosin $(200 \mathrm{~g} / \mathrm{l}), 10 \mathrm{ml}$ acetone, and $80 \mathrm{ml}$ distilled water to obtain a 1:20 dilution. The suspension was mixed for 30 seconds and added to the counting chamber. The total number of eosinophils within the ruled area was counted and at least four chambers were counted. The results were expressed as total eosinophils per litre. Counts were performed by one observer without knowledge of the patient's histamine $\mathbf{P C}_{20}$. The coefficient of variation for eosinophil counts obtained by this method was consistently less than $10 \%$.

\section{STATISTICAL METHODS}

Natural logarithmic transformations were applied to all histamine $\mathbf{P C}_{20}$ values before analysis. Correlation coefficients were calculated by use of linear regression analysis by the method of least squares.

\section{Results}

Individual eosinophil counts and histamine $\mathbf{P C}_{20}$ values are shown in the table. There was a wide range of histamine $\mathrm{PC}_{20}$ values, ranging from 0.03 to 13.5 $\mathrm{mg} / \mathrm{ml}$ for atopic subjects and from 0.03 to 15.0 $\mathrm{mg} / \mathrm{ml}$ for non-atopic subjects. Similarly, the eosinophil count showed wide variation, with a mean value of 383 (range 55-915) $\times 10^{6} / 1$ for the atopic subjects and 310 (range 30-690) $\times 10^{6} / 1$ for the nonatopic subjects. The mean $\mathrm{FEV}_{1}$ was $84 \%$ predicted 
(range $60-112 \%$ ) for the atopic subjects and $79 \%$ (range $50-107 \%$ ) for the non-atopic subjects.

There was a significant inverse correlation between baseline eosinophil count and $\log$ histamine $\mathbf{P C}_{\mathbf{2 0}}$. For all 23 subjects, $r=-0.71(p<0.001)$; for the 14 atopic subjects, $r=-0.74(p<0.01)$; for the nine non-atopic subjects, $r=-0.68(p<0.05)$, see figure 1. There was an inverse correlation between baseline eosinophil count and baseline $\mathrm{FEV}_{1}$ in the non-atopic subjects $(r=-0.65 ; p<0.05)$ but no such correlation in the atopic group (fig 2 ). There was no correlation between baseline $\mathrm{FEV}_{1}$ and histamine $\mathrm{PC}_{20}$ for either group and no correlation between age and histamine $\mathrm{PC}_{20}$ or age and eosinophil count.

\section{Discussion}

Peripheral blood eosinophilia in asthmatic patients has been recognised since the early 1900 s but individual eosinophil counts have shown wide variation in patients who are clinically stable. ${ }^{3}$ Eosinophil counts show a diurnal variation with maximal values at night, ${ }^{9}$ and this appears to be related to endogenous cortisol levels. Other factors influencing the eosinophil count include physical and mental stress, intercurrent infection, and drug treatment such as systemic corticosteroids, ${ }^{4}$ sympathomimetic agents, and aminophylline. ${ }^{10}$ For these reasons histamine challenge testing was always performed between 10.00 and 12.00 hours and drugs were withdrawn beforehand.

Bronchial responsiveness can be increased by several factors, including chemical exposure to ozone $^{11}$ and respiratory viral infections. ${ }^{12}$ These agents may lower the threshold for bronchial smootho muscle contraction during provocation testing byo inducing bronchial inflammation. The eosinophilo may have a causative role in the development of increased bronchial responsiveness. Major basic $\stackrel{\mathbb{Q}}{\varrho}$ protein, present in the crystalloid core of its majoro granule, in low concentrations can damage various mammalian target cells and organs. ${ }^{13}$ Concentrations. comparable with those found in the sputum of $\vec{\omega}$ patients with asthma have been shown to be ciliostatic and to induce damage to tracheal mucosal cells. $^{2}$

The presence of eosinophils in the peripheral blood may not reflect what is happening at other sites of directly but eosinophils were found to be prominent $N$ in bronchoalveolar lavage fluid from patients with음 mild asthma. ${ }^{14}$ In a previous study by one of the authors, in which blood eosinophil counts were exam- $\subseteq$ ined in different clinical patterns of asthma, ${ }^{3}$ blood $\widehat{\sigma}$ eosinophilia was almost invariable in chronic wors- $\overrightarrow{0}$ ening asthma, a condition in which increased bron- $\stackrel{\infty}{-}$ chial reactivity would be expected. Paradoxically, acute severe asthma was associated with blood eosinopenia, possibly because it provoked a stress response with increased cortisol secretion. ${ }^{15}$ Adrenal corticosteroids are a potent cause of eosinopenia; $\stackrel{0}{\mathbb{Q}}$ four hours after a $100 \mathrm{mg}$ dose of hydrocortisone $\varrho$ eosinophils were almost absent from peripheralö blood. ${ }^{16}$

An association between the peripheral blood eosinophil count and the level of bronchial:responsiveness after methacholine has been shown in
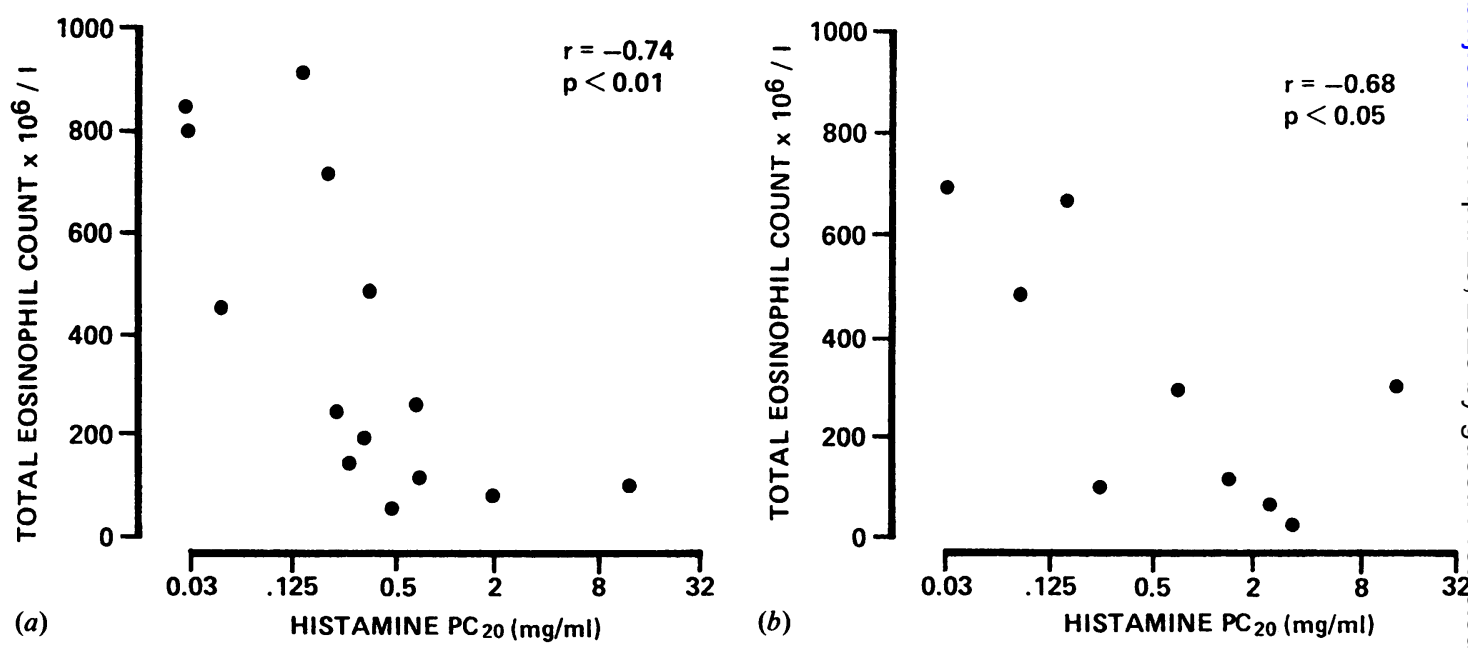

Fig 1 Relationship between total eosinophil count and histamine $P C_{20}(a)$ in the 14 atopic patients and $(b)$ in the nine non-atopic patients. 

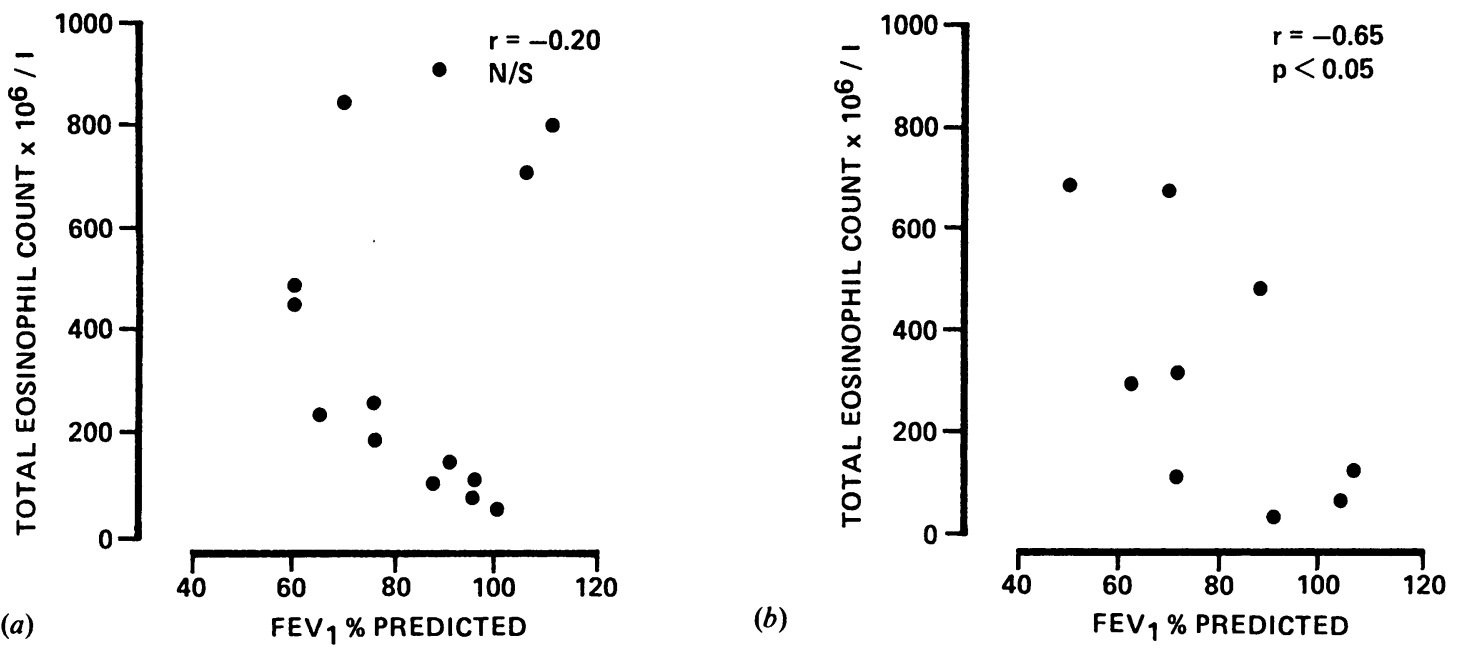

Fig 2 Relationship between total eosinophil count and baseline FEV (\% predicted) (a) in the 14 atopic patients and (b) in the nine non-atopic patients.

subjects who developed an allergen induced late phase reaction, and the eosinophil count increased 24 hours after challenge in these subjects. ${ }^{5}$ Our findings are consistent with the initial observations in this study. Total eosinophil counts correlated inversely with $\mathrm{FEV}_{1}$ in systemic steroid dependent non-atopic asthma in one study, in keeping with our observations, though our non-atopic subjects were not taking systemic steroids.

Smoking has been shown to increase both bronchial responsiveness, ${ }^{17}$ and absolute eosinophil count, ${ }^{18}$ but since only three of our subjects were current smokers (table), this factor is unlikely to have confounded our results.

A reduction in eosinophil count might be expected to have some beneficial effect on disease activity, either directly or indirectly; and indeed one effect of systemic corticosteroid treatment is a reduction in eosinophil count. ${ }^{4}$ The effect of systemic corticosteroid treatment on bronchial responsiveness, however, is not fully established, and studies have shown conflicting results. ${ }^{19-21} \mathrm{~A}$ recent study of subjects with stable asthma showed that methylprednisolone protected against increased bronchial responsiveness to carbachol, but the effect on eosinophil count was not determined. ${ }^{22}$

Treatment with either inhaled sodium cromoglycate $^{23}$ or inhaled cortiscosteroid ${ }^{24} 25$ produces a small reduction in bronchial responsiveness. Our subjects who were having regular treatment with these agents continued to take them and a similar proportion of treated and untreated subjects were present in the two groups (table). When data on these treated subjects were excluded from the analysis, the same relationship between eosinophil count and bronchial responsiveness was apparent.

We conclude that there is a relationship between the peripheral blood eosinophil count and nonspecific bronchial responsiveness in both atopic and non-atopic asthma.

We thank the chest physicians at Fazakerley Hospital for allowing us access to patients under their care.

\section{References}

1 Schatz M, Wasserman S, Patterson R. The eosinophil and the lung. Arch Intern Med 1982;142:1515-9.

2 Gleich GJ, Frigas E, Loegering DA, Wassom DL, Steinmuller D. Cytotoxic properties of the eosinophil major basic protein. J Immunol 1979;123:2925-7.

3 Luksza AR, Jones DK. Comparison of whole-blood eosinophil counts in extrinsic asthmatics with acute and chronic asthma. Br Med J 1982;285:1229-31.

4 Horn BR, Robin ED, Theodore J, Van Kessel A. Total eosinophil counts in the management of bronchial asthma. N Engl J Med 1975;292:1152-5.

5 Durham SR, Kay AB. Eosinophils, bronchial hyperreactivity and late-phase asthmatic reactions. Clin Allergy 1985;15:411-8.

6 Cockcroft DW, Killian DN, Mellon JJA, Hargreave FE. Bronchial reactivity to inhaled histamine: a method and clinical survey. Clin Allergy 1977;7:235-43.

7 Cotes JE. Lung Function: principles and application in medicine. 4th ed. Oxford: Blackwell Scientific Publications, 1979.

8 Dacie JV, Lewis SM. Eosinophil counts by counting chamber method. In: Practical haematology. 6th ed. Edinburgh: Churchill Livingstone, 1984:42-3. 
9 Dahl R. Diurnal variation in the number of circulating eosinophil leucocytes in normal controls and asthmatics. Acta Allergol 1977;32:301-3.

10 Ohman JN jun, Lawrence M, Lowell FC. Effect of propranolol on the responses of cortisol, isoproterenol and aminophylline. J Allergy Clin Immunol 1972;50: 151-6.

11 Golden JA, Nadel JA, Boushey HA. Bronchial hyperreactivity in healthy subjects after exposure to ozone. Am Rev Respir Dis 1978;118:287-91.

12 Empey DM, Laitinen LA, Jacobs L, Gold WM, Nadel JA. Mechanisms of bronchial hyperreactivity in normal subjects after upper respiratory tract infection. Am Rev Respir Dis 1976;113:131-9.

13 Gleich GJ, Loegering DA, Frigas E, Wassom DL, Solley GO, Mann KG. The major basic protein of the eosinophil granule: physiochemical properties, location and function. In: Mahmoud AF, Austen KF, eds. The eosinophil in health and disease. New York: Grune and Stratton, 1980:79-97.

14 Diaz P, Galleguillos FR, Gonzalez MC, Pantin CFA, Kay AB. Bronchoalveolar lavage in asthma: the effect of disodium cromoglycate (cromolyn) on leucocyte counts, immunoglobulins and complement. J Allergy Clin Immunol 1984;74:41-8.

15 Collins JV, Clark TJH, Brown D, Townsend J. The use of corticosteroids in the treatment of acute asthma. $Q$ J Med 1975;44:259-73.

16 Gordon AS. Some aspects of hormonal influences upon the leucocytes. Ann NY Acad Sci 1955;59:907-27.

17 Taylor RG, Joyce H, Gross E, Holland F, Pride NB.
Bronchial reactivity to inhaled histamine and annual rate of decline in $\mathrm{FEV}_{1}$ in male smokers and exsmokers. Thorax 1985;40:9-16.

18 Taylor RG, Gross E, Joyce H, Holland F, Pride NB. Smoking, allergy and the differential white blood cell $\overline{\bar{c}}$ count. Thorax 1985;40:17-22.

19 Tiffeneau R, Donoyer P. Action de la cortisone sur $\stackrel{\mathbb{Q}}{\stackrel{2}{2}}$ l'hypersensibilité cholinergique pulmonaire de l'asthmatique. Presse Méd 1956;64:719-21.

20 Wolfe JD, Rosenthal RR, Bleecker E, Laube B, Norman PS, Permutt S. The effect of corticosteroids on choli- $\vec{\omega}$ nergic hyperreactivity [abstract]. $J$ Allergy Clin Immunol 1979;63:162.

21 Atkins JA, Schleuter DP, Fink JN. The effect of corticosteroids on methacholine inhalation in symptomatic $N$ bronchial asthma. $J$ Allergy 1968;41:209-16.

22 Israel RH, Poe RH, Wicks CM, Greenblatt DW, Kallay of MC. The protective effect of methylprednisolone on carbachol-induced bronchospasm. Am Rev Respir Dis 1984;130:1019-22.

23 Rocchiccioli K, Pickering CAC, Cole M, Horsfield N. $\subseteq$ Effect of regular treatment with sodium cromoglycate $\overline{\mathbb{D}}$ on non-specific bronchial hyperreactivity [Abstract]. Thorax 1984;39:706.

24 Hartley JPR. Effect of budesonide on bronchial hyper-. reactivity [Abstract]. Thorax 1984;39:706.

25 Ryan G, Latimer KM, Juniper EF, Roberts RS, Hargreave FE. Effect of beclomethasone dipropionate on bronchial responsiveness to histamine in controlled nonsteroid-dependent asthma. J Allergy Clin Immunol $\frac{\mathrm{\Phi}}{\mathrm{Q}}$ 1985;75:25-30. 